\title{
Distinct effect of Chrysanthemum indicum Linné extracts on isoproterenol-induced growth of human hepatocellular carcinoma cells
}

\author{
AIHUA YUAN ${ }^{1,2}$, ZONGFANG LI $^{1}$, XINQIU LI $^{3}$, SHANYONG YI ${ }^{4}$, SHUKUI WANG $^{2}$, \\ KAIWANG $\mathrm{SHI}^{2}$ and JIANMIN BIAN ${ }^{2}$ \\ ${ }^{1}$ Department of General Surgery, Second Affiliated Hospital of Medical College of Xi'an Jiaotong University, \\ Xi'an; ${ }^{2}$ Department of Oncosurgery, Nanjing First Hospital Affiliated to Nanjing Medical University, \\ Nanjing; Departments of ${ }^{3}$ Hepatobiliary Surgery, ${ }^{4}$ Cancer Center, First Affiliated Hospital of \\ Medical College of Xi'an Jiaotong University, Xi'an, P.R. China
}

Received May 15, 2009; Accepted July 27, 2009

DOI: 10.3892/or_00000575

\begin{abstract}
Chrysanthemum indicum Linné (Asteraceae) is a common Chinese herbal medicine that has been traditionally used for the treatment of inflammation, hypertension and neoplastic diseases in China. However, the mechanism that account for the inhibitory activity of Chrysanthemum indicum Linné against cancer cells is poorly understood. We investigated the effect of Chrysanthemum indicum Linné extracts (CILE) on isoproterenol (ISO) induced growth of human hepatocellar carcinoma (HCC) cells in correlation with the intracellular activity of MAPK/ERK1/2. We found that CILE was effective in attenuating the mitogenic effect of ISO on both HepG2 and MHCC97H cells. The inhibitory effect of CILE was mediated by inhibiting the ISO-induced activation of MAPK/ ERK1/2 via B2-AR in tumor cells. Our findings will be helpful in understanding the anticancer mechanism of CILE.
\end{abstract}

\section{Introduction}

Chrysanthemum indicum Linné (Asteraceae) is a common Chinese herbal medicine that has been traditionally used for the treatment of inflammation, hypertension and neoplastic diseases in China (1-3). Modern pharmacological research demonstrates that chrysanthemum indicum Linné extracts (CILE) possess several effective compositions such as

Correspondence to: Dr Zongfang Li, Department of General Surgery, Second Affiliated Hospital of Medical College of Xi'an Jiaotong University, 157 Xiwu Road, Xi'an 710004, P.R. China E-mail: zongfangli@yahoo.cn

Key words: Chrysanthemum indicum Linné extracts, isoproterenol, ß2-adrenergic receptor, extracellular signal-regulated kinase 1/2, hepatocellular carcinoma flavonoids, terpenoids and phenolic compounds that have antibacterial, antivirus, anti-inflammatory, anti-sympathetic, antioxidant, and anti-neoplastic functions (4-7). These data indicate that there are great chances of finding new anticancer agents from Chinese pharmacy. However, the traditional use of Chrysanthemum indicum Linné for treatment of cancers in Chinese medicine is rather perplexing and the molecular mechanisms that account for the inhibitory activity of Chrysanthemum indicum Linné against cancer cells are poorly understood.

Recent studies emphasize the influences of psychological stress on cancer progression. The effects of psychological stress on cancer cells are mediated by the key stress hormones and their corresponding receptors $(8,9)$. A number of studies demonstrate that catecholamine activates the mitogenactivated protein kinase (MAPK)/extracellular signal-regulated kinase1/2 (ERK1/2) signaling pathway via 32 -adrenergic receptor to promote the growth of cancer cells (10-12). The ERK pathway is a component of the MAPK cascade and consists of two isoenzymes, namely ERK $1 / 2$, also called p44ERK1 and p42ERK2. Activated ERK1/2 translocate into nuclei and activate transcription factors to increase transcription of genes relevant for cell growth and invasion $(13,14)$. Recent studies demonstrate that CILE also modulate the activity of MAPK/ERK1/2 in immune and cardiovascular cells that contribute to the anti-inflammatory, anti-sympathetic and antioxidant effects (15-18). These data indicate that CILE possess a certain antagonistic function against stress hormones.

In the present study, we investigated the antagonistic effect of CILE on the B-AR agonist isoproterenol (ISO) induced growth of human hepatocellar carcinoma (HCC) cells, in correlation with the adrenergic receptors and the activity of ERK1/2 in tumor cells.

\section{Materials and methods}

Chemicals and antibodies. ( \pm )-Isoproterenol hydrochloride and ( \pm )-1-[2,3-(Dihydro-7-methyl-1H-inden-4-yl)oxy]-3-[(1methylethyl)amino]-2-butanol (ICI 118551) were obtained 
from Sigma-Aldrich Corporation (St. Louis, MO, USA). Rabbit antibody against p44/42-MAPK(ERK1/2) was obtained from Santa Cruz Biotech (Santa Cruz, CA, USA) and rabbit antibody against phospho-ERK1/2 (T202/Y204) was obtained from R\&D Systems (R\&D Systems, Inc., USA). The specific secondary antibody and the specific MEK1/2 inhibitor U0126 were obtained from Calbiochem-Novabiochem Corporation (San Diego, CA, USA).

Plant material. The dried flowers of Chrysanthemum indicum were extracted twice with $70 \%$ ethanol (with $2 \mathrm{~h}$ reflux), and then concentrated under reduced pressure. The concentrated CILE was filtered, lyophilized, and dissolved in dimethyl sulfoxide (DMSO was kept $\leq 0.1 \%$ ) and then filtered through a $0.2 \mu \mathrm{m}$ syringe filter.

Cell culture and treatment. Human normal liver cell line HL7702 (L-02) and human hepatoma cell line HepG2 were obtained from ATCC (Rockville, MD, USA), and the high invasive human hepatocellular carcinoma cell line MHCC97H was obtained from Liver Cancer Institute of Zhongshan Hospital, Fudan University (Shanghai, China). HepG2 cells were maintained and propagated in RPMI-1640 supplemented with $10 \%$ fetal bovine serum (HyClone, Logan, UT, USA). MHCC $97 \mathrm{H}$ cells were maintained and propagated in vitro by serial passage in Dulbecco's modified Eagle's medium (DMEM) with high glucose supplemented with $15 \%$ fetal bovine serum. All cultured cells were maintained at $37^{\circ} \mathrm{C}$ in a humidified atmosphere containing $5 \% \mathrm{CO}_{2}$ and experiments were done using $70-80 \%$ confluent cultures.

Cell proliferation assay. Proliferation of HepG2 and MHCC97H cells was investigated through MTT methods. Briefly, $1 \times 10^{4}$ cells per well were plated into flat-bottomed 96-well plates (Costar, Corning, NY, USA). After 24 h, cells were serum-starved overnight. The next day, cells were incubated with different concentrations of ISO in absence or presence of ICI 118551, U0126 and CILE for 12, 24, 48 and $96 \mathrm{~h}$. Control wells were treated with $0.1 \%$ DMSO alone. Subsequently, $20 \mu \mathrm{l}$ of MTT $(5 \mathrm{~g} / \mathrm{l})$ was added to each well and incubated for an additional $4 \mathrm{~h}$. Plates were centrifuged for $5 \mathrm{~min}$ at $1000 \mathrm{rpm}$, and the medium was carefully discarded. The formed formazan crystals were dissolved in $100 \mu 1$ of DMSO, and absorbance was read at $570 \mathrm{~nm}$ using a spectrophotometer.

Western blot analysis. HepG2 and MHCC97H cells were washed twice in phosphate-buffered saline (PBS), lysed in ice-cold radioimmune precipitation (RIPA) buffer, and then centrifuged for $10 \mathrm{~min}$ at $4^{\circ} \mathrm{C}$. Supernatant was collected and protein concentrations were determined and adjusted to $2 \mathrm{mg} / \mathrm{ml}$ using the Bio-Rad kit (Bio-Rad Laboratories, Hercules, CA, USA). Cell lysates were mixed with $3 \mathrm{X}$ Laemmli buffer and heated for $5 \mathrm{~min}$ at $95^{\circ} \mathrm{C}$. They were then resolved by SDS-PAGE (10\% polyacrylamide gels), transferred to polyvinylidene difluoride membrane (Immobilon $^{\mathrm{TM}}$; Millipore Corp.) by electroblotting. The membrane was blotted with $10 \%$ nonfat milk, washed in TBS Tween and incubated with primary rabbit polyclonal antibodies overnight at $4^{\circ} \mathrm{C}$. After washing with TBS Tween, they were incubated with secondary antibody solution (horseradish peroxidase

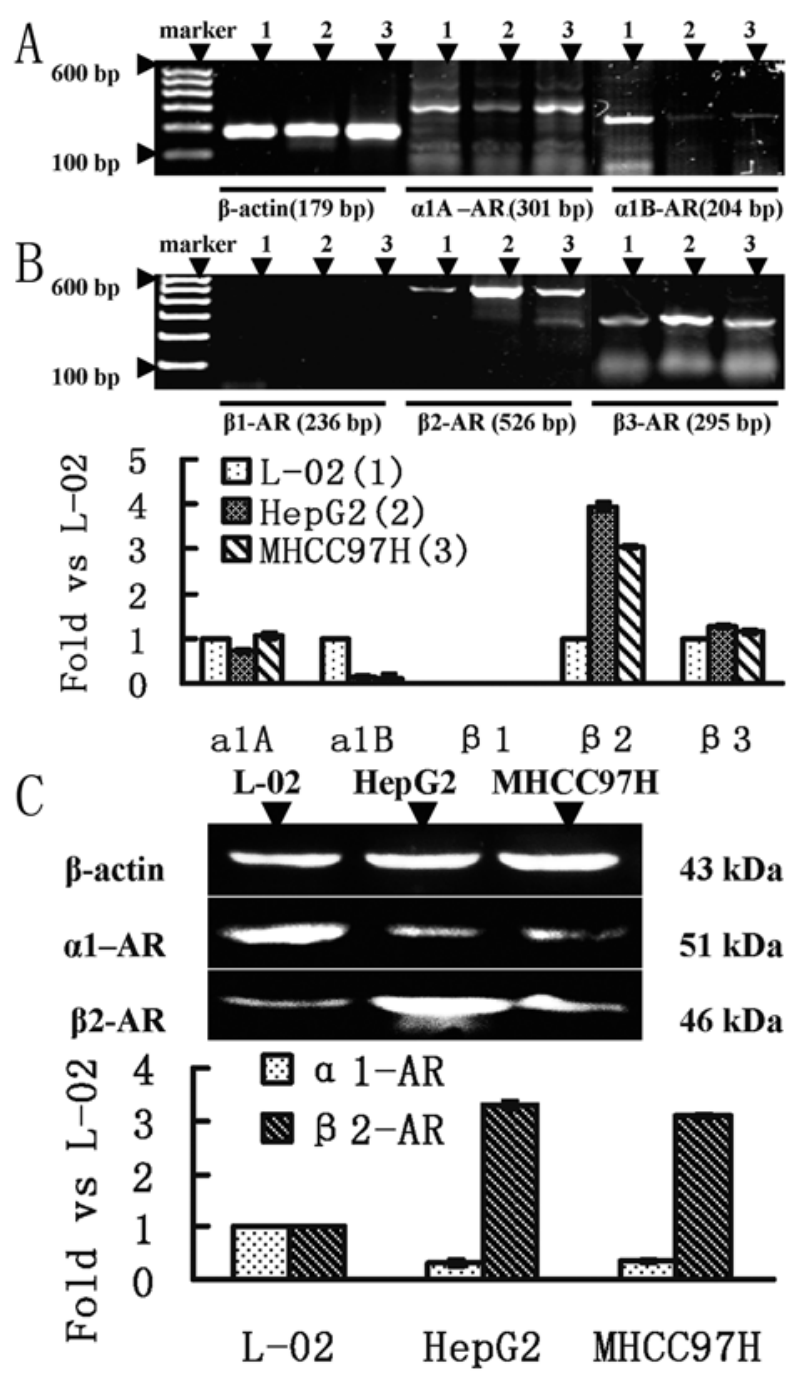

Figure 1. Expression of $\alpha 1$ - and $\beta-A R$ mRNA in HL-7702, HepG2 and MHCC 97H cells. The expression of $\alpha 1 \mathrm{~A} / \mathrm{B}-$ and $31 / 2 / 3-\mathrm{AR}$ mRNA was evaluated using reverse transcription-PCR. The level of $\alpha 1$ - and B2-AR proteins was detected using Western blotting. The results are presented as fold change versus control (L-02). (A) The expression of $\alpha 1 \mathrm{~A}-$ and $\alpha 1 \mathrm{~B}$ AR mRNA. (B) The expression of B1-, B2- and B3-AR mRNA. (C) The expression of $\alpha 1$ - and $\beta 2$-AR proteins. $\alpha 1$-protein was detected using a specific antibody against both $\alpha 1 \mathrm{~A}$ - and $\alpha 1 \mathrm{~B}-\mathrm{AR}$. The results are presented as fold change versus control (L-02).

conjugated $\mathrm{IgG}$ ) for $60 \mathrm{~min}$ at room temperature. Membranes were washed again with TBS Tween before detection using the enhanced chemiluminescence detection system (Amersham Pharmacia Biotech, Piscataway, NJ, USA). The following primary antibodies were used at dilutions: anti-ERK1/2, 1:800; anti-phospho-ERK1/2, 1:800; anti- $\beta$-actin, 1:400; secondary antibody was used at dilutions of $1: 10000$.

Flow cytometric analysis. HepG2 and MHCC97H cells were plated in six-well plates at $3 \times 10^{5}$ per well. Cells were serumstarved overnight before compound treatment. After incubated with ISO in absence or presence of ICI 118551, U0126 and CILE for the indicated times, cells were harvested by trypsinization and washed with PBS. Cells were fixed in ice-cold $80 \%$ ethanol, washed, and resuspended in $1 \mathrm{ml} \mathrm{PBS}$; treated with $10 \mu \mathrm{l}$ RNase A $(21 \mathrm{mg} / \mathrm{ml})$; and stained with $5 \mu 1$ propidium iodide at $1 \mathrm{mg} / \mathrm{ml}$ for $30 \mathrm{~min}$ at room temperature 


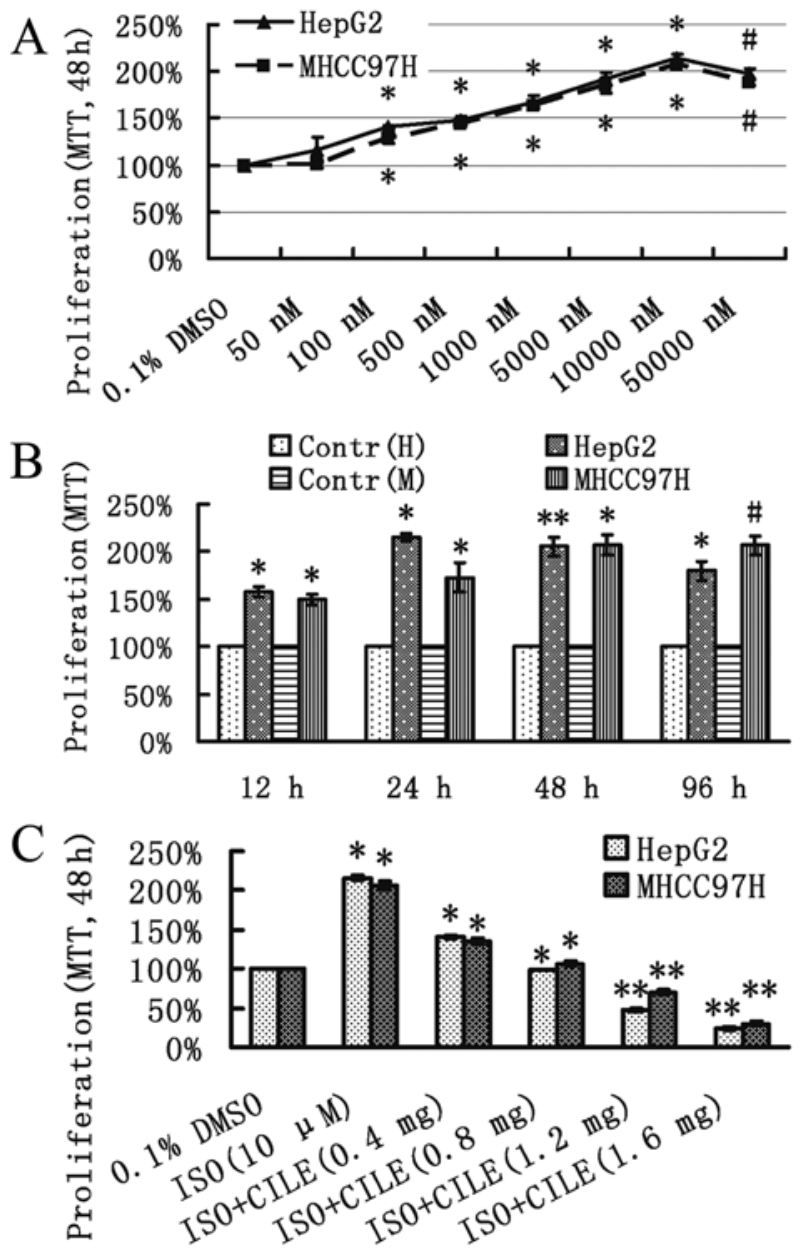

Figure 2. Chrysanthemum indicum Linné extract (CILE) competently attenuated the growth-promoting effect of isoproterenol (ISO) on HepG2 and MHCC97H cells. Proliferation of HepG2 and MHCC97H cells was assessed by MTT assay. Data were the mean \pm SEM of three separate experiments and expressed as a percentage of the control $\mathrm{OD}$ value from wells without stimulants (0.1\% DMSO). (A) Cells were serum-starved overnight and then incubated with increasing doses of ISO for $48 \mathrm{~h}$. ISO dose-dependently stimulated the growth of HepG2 and MHCC97H cells. ${ }^{*} \mathrm{p}<0.05$ versus control $\left(0.1 \%\right.$ DMSO). ${ }^{*} \mathrm{p}<0.05$ versus control and $\mathrm{p}>0.05$ versus $5000 \mathrm{nM}$ of ISO. (B) Cells were incubated with $10 \mu \mathrm{M}$ of ISO for $12,24,48$ and 96 h. ${ }^{*} \mathrm{p}<0.05$ versus control. ${ }^{* *} \mathrm{p}<0.05$ versus control and $\mathrm{p}>0.05$ versus $24 \mathrm{~h} .{ }^{\#} \mathrm{p}<0.05$ versus control and $\mathrm{p}>0.05$ versus $48 \mathrm{~h}$. ISO transiently stimulated the growth of HepG2 and MHCC97H cells. (C) Cells were incubated with $10 \mu \mathrm{M}$ of ISO for $48 \mathrm{~h}$ in presence of increasing doses of CILE $(0.4-1.6 \mathrm{mg} / \mathrm{ml}) .{ }^{*} \mathrm{p}<0.05$ versus ISO. ${ }^{* *} \mathrm{p}<0.05$ versus control. CILE dose-dependently inhibited the growth of HepG2 and MHCC97H cells stimulated by ISO.

in the dark. The stained cells were analyzed by flow cytometry (BD LSRII System, BD Biosciences, San Jose, CA, USA). Gating was set to exclude cell debris, cell doublets, and cell clumps. To evaluate the cell cycle distribution of apoptotic cells in response to serum-deprivation, the treated cells were washed in PBS, resuspended in $100 \mathrm{ml}$ binding buffer containing FITC-conjugated Annexin V (Becton Dickinson, San Jose, CA, USA) and propidium iodide (PI) to discriminate apoptotic cells from live cells and necrotic cells. Annexin $\mathrm{V}(+) / \mathrm{PI}(-)$ and Annexin $\mathrm{V}(+) / \mathrm{PI}(+)$ represent the cells in early apoptosis and late apoptosis/necrosis, respectively.

Statistical analysis. Immunoblot signals were first quantitated using densitometry and ImageJ software (version $1.34 \mathrm{~s}$; by
Wayne Rasband, NIH, Bethesda, MD, USA). Results were expressed as the mean \pm SEM of three separate experiments and analyzed by the computer program SPSS 10.0 for Windows (SPSS Inc., Chicago, IL), using one-way analysis of variance (ANOVA) followed by the Turkey's t-test. $\mathrm{P}<0.05$ were considered statistically significant.

\section{Results}

Chrysanthemum indicum Linné extract (CILE) inhibited the growth-promoting effect of the $\beta$-AR agonist isoproterenol (ISO) on HepG2 and MHCC97H. Our previous study demonstrated that $\alpha 1$-adrenergic receptor ( $\alpha 1$-AR) was downregulated while $B 2$-adrenergic receptor (B2-AR) was upregulated in both HepG2 and MHCC97H cells (Fig. 1A-C), we selected the specific B-AR agonist isoproterenol (ISO) as a stimulant. The growth-promoting effect of ISO and the inhibitory effect of CILE on HepG2 and MHCC97H cells were determined using the MTT assay. ISO dose-dependently stimulated the proliferation of HepG2 and MHCC97H cells (Fig. 2A and B). The growth enhancement was initiated at a dose of $100 \mathrm{nM}$ of ISO and peaked at a dose of $10000 \mathrm{nM}$ of ISO with the maximum increases in proliferation $(\mathrm{HepG} 2$ was $215 \pm 2 \%$ and $\mathrm{MHCC} 97 \mathrm{H}$ was $207 \pm 4 \%$ versus control, respectively, $\mathrm{p}<0.05)$. Strikingly, the ISO-induced growth of HepG2 and MHCC97H cells was significantly inhibited in the presence of CILE (from $0.4 \mathrm{mg} / \mathrm{ml}$ to $1.6 \mathrm{mg} / \mathrm{ml}$ ), and the maximum inhibitory effect of CILE was present at the dose of $1.6 \mathrm{mg} / \mathrm{ml}$. The maximum decrease in proliferation of HepG2 was $89 \pm 2 \%$, and the maximum decrease in proliferation of $\mathrm{MHCC} 97 \mathrm{H}$ was $86 \pm 3 \%$ relatively to the subgroup of ISO in absence of CILE, $\mathrm{p}<0.05$ (Fig. 2C).

Isoproterenol activated MAPK/ERK1/2 in HepG2 and $M H C C 97 H$ cells. We then were curious about whether ISO could activate MAPK/ERK1/2 signaling pathway in HepG2 and MHCC97H cells. ISO $(10 \mu \mathrm{M})$ was added to the medium and the levels of phosphorylated-ERK1/2 (pERK1/2) were determined by Western blotting. The addition of ISO resulted in an immediate activation of ERK1/2 in both HepG2 and MHCC97H cells (Fig. 3A and B). As early as 15 min after the addition of ISO, pERK1/2 was increased by an average of 3.49/3.02-fold in HepG2 (Fig. 3A) and 3.15/2.33-fold in MHCC97H (Fig. 3B). We used the selective antagonist of B2-AR, ICI 118551 to confirm the B2-AR signaling. The specificity of ISO-induced phosphorylation of ERK1/2 was demonstrated using the MEK-specific inhibitor, U0126. Both ICI $118551(5 \mu \mathrm{M})$ and U0126 $(10 \mu \mathrm{M})$ efficiently blocked the increases of pERK1/2 (Fig. 3C and D).

Mitogenic effect of isoproterenol on HepG2 and $\mathrm{MHCC} 97 \mathrm{H}$ cells was significantly attenuated by Chrysanthemum indicum Linné extract. We added CILE to the medium to see whether the ISO-induced activation of MAPK/ERK $1 / 2$ could be blocked. Cells were incubated with $1.2 \mathrm{mg} / \mathrm{ml}$ of CILE in absence or presence of $10 \mu \mathrm{M}$ of ISO. CILE slightly inhibited the activities of ERK1/2 in absence of ISO. However, the inhibitory effect of CILE on ERK1/2 was more significant in the presence of ISO (Fig. 4A and B). We further examined the inhibitory effect of CILE on the proliferation of HepG2 

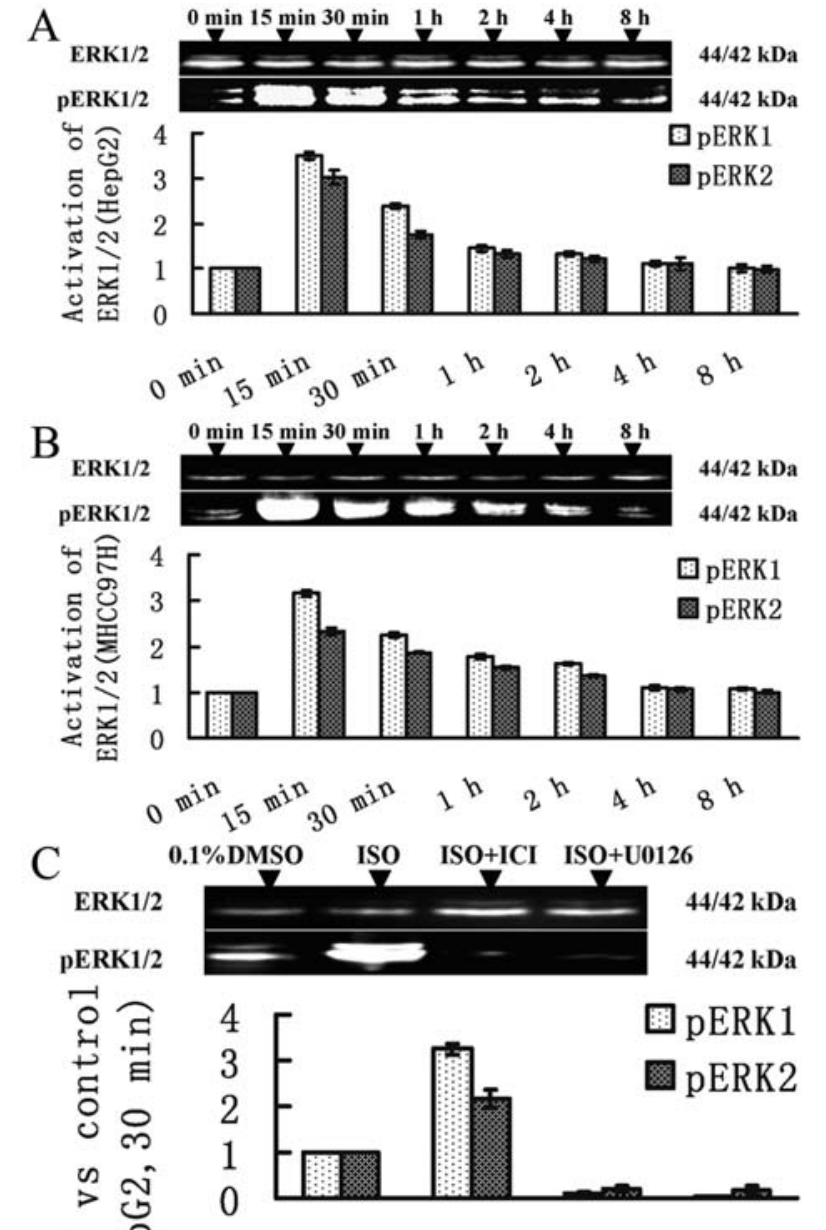

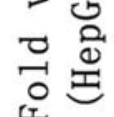
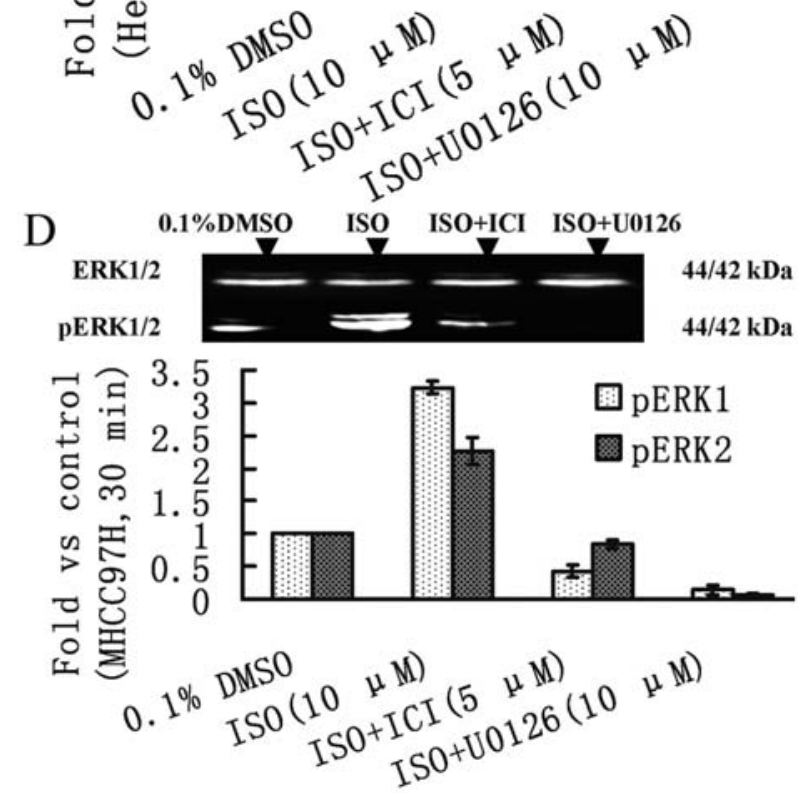

Figure 3. ISO activated MAPK/ERK1/2 in HepG2 and MHCC97H cells. (A and B) Cells were serum-starved overnight and incubated with $10 \mu \mathrm{M}$ of ISO for $15 \mathrm{~min}, 30 \mathrm{~min}, 1 \mathrm{~h}, 2 \mathrm{~h}, 4 \mathrm{~h}$ and $8 \mathrm{~h}$. The levels of PhosphorylatedERK1/2 were determined by Western blotting. The results are presented as fold change versus control ( $0.1 \%$ DMSO). ISO transiently activated ERK $1 / 2$ in HepG2 and MHCC97H cells. (C and D) HepG2 and MHCC97H cells were serum-starved overnight and then incubated with $10 \mu \mathrm{M}$ of ISO for $30 \mathrm{~min}$ in absence or presence of $5 \mu \mathrm{M}$ of ICI 118551 (ICI, a selective antagonist of B2-AR) and $10 \mu \mathrm{M}$ of U0126 (a specific MEK inhibitor). ICI and U0126 were added 30 min before ISO. The levels of PhosphorylatedERK1/2 were determined by Western blotting. The results are presented as fold change versus control (0.1\% DMSO). ISO activated ERK1/2 via B2-AR in HepG2 and MHCC97H cells.
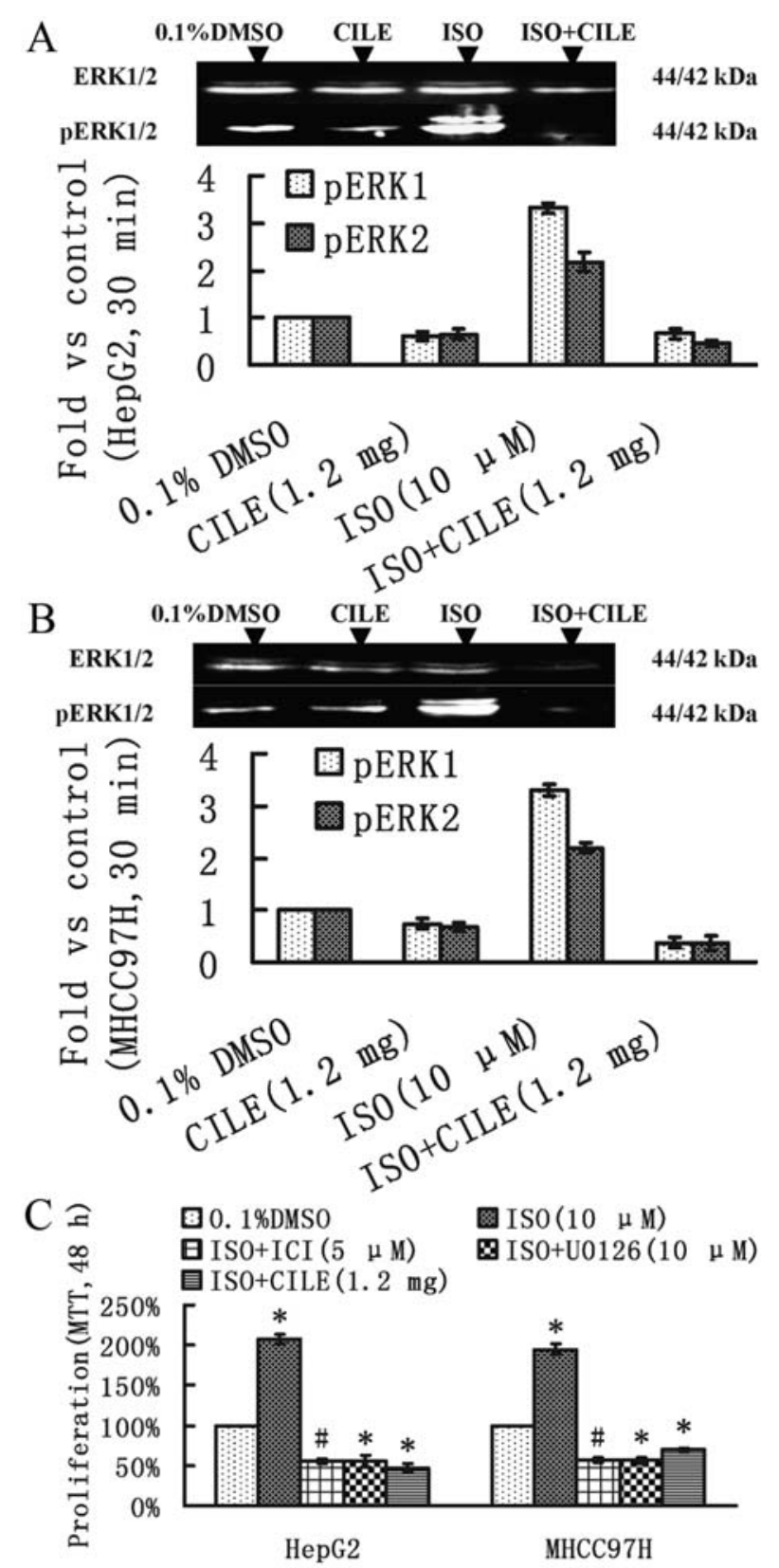

Figure 4. CILE effectively attenuated the stimulatory effect of ISO on MAPK/ERK1/2 in HepG2 and MHCC97H cells. (A and B) Cells were serum-starved overnight and incubated with $1.2 \mathrm{mg} / \mathrm{ml}$ of CILE for $60 \mathrm{~min}$ in absence or presence of $10 \mu \mathrm{M}$ of ISO. CILE was added $30 \mathrm{~min}$ before ISO. Phosphorylated-ERK1/2 was determined by Western blotting. Results are presented as fold change versus control (0.1\% DMSO). ISO-induced activation of ERK1/2 was significantly inhibited either by CILE. (C) HepG2 and MHCC97H cells were incubated with $10 \mu \mathrm{M}$ of ISO for $48 \mathrm{~h}$ in the absence or presence of $5 \mu \mathrm{M}$ of ICI $118551,10 \mu \mathrm{M}$ of U0126, or $1.2 \mathrm{mg} / \mathrm{ml}$ of CILE. ICI 118551, U0126 and CILE were added $30 \mathrm{~min}$ before ISO. Cell proliferation was assessed by MTT assay. Results are presented as percent of control $(0.1 \% \mathrm{DMSO}) .{ }^{*} \mathrm{p}<0.05$ versus control. ${ }^{*} \mathrm{p}<0.05$ versus control and $p>0.05$ versus U0126. The growth-promoting effect of ISO was significantly attenuated by ICI, U0126 and CILE.

and MHCC97H cells in comparison with that of ICI 118551 and U0126. The results showed that the growth-promoting effect of ISO on HepG2 (ISO: 207.1 $\pm 5.9 \%$; ICI: $55.6 \pm 2.5 \%$; U0126: $56.4 \pm 5.6 \%$; CILE: $47.3 \pm 6 \%$ versus control, respectively, $\mathrm{p}<0.05$ ) and MHCC97H (ISO: $195.1 \pm 6 \%$; ICI: 57.2 $\pm 3.3 \%$; U0126: $56.3 \pm 4.1 \%$; CILE: $69.5 \pm 2.3 \%$ versus 
A

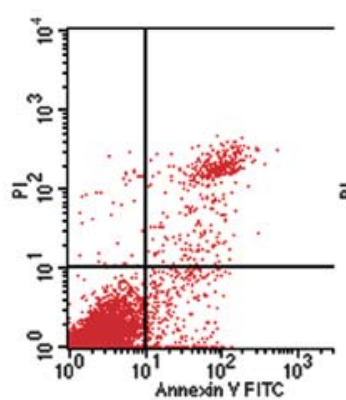

A1:DMSO

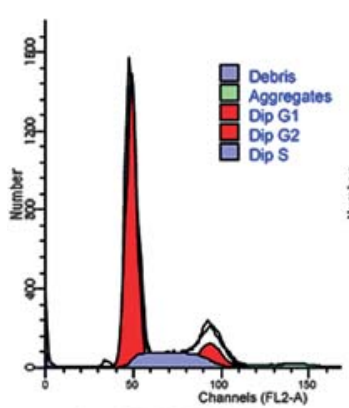

A6:DMSO

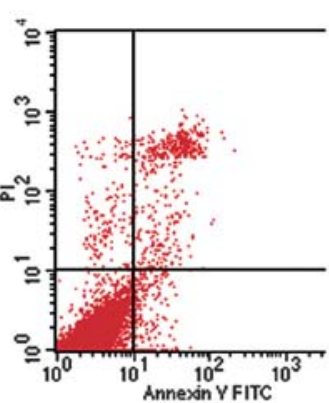

A2:ISO

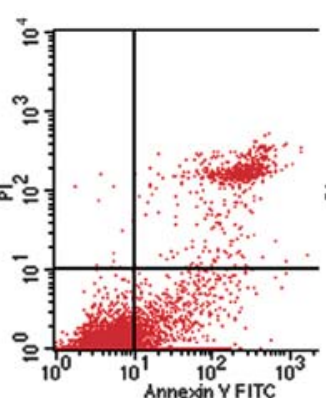

A3:ISO+ICI

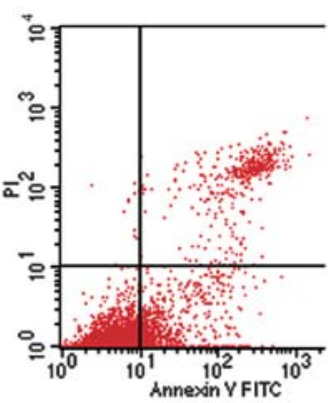

A4:ISO+U0126

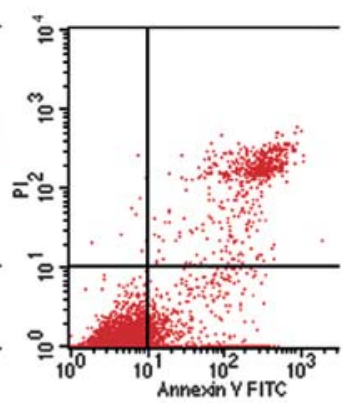

A5:ISO+CILE

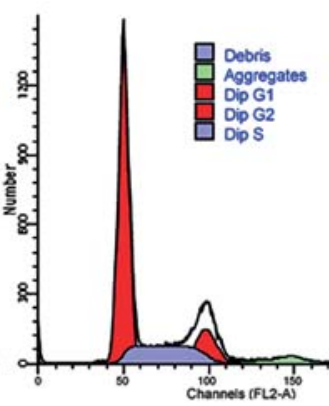

A7:ISO
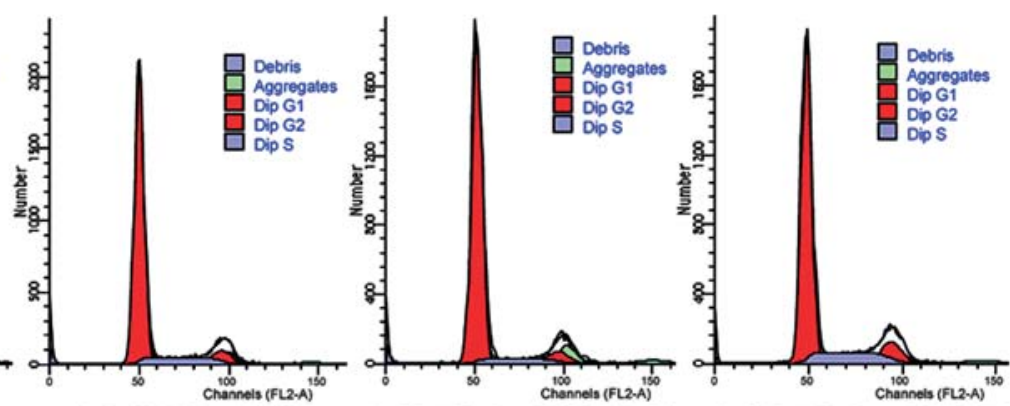

A9:ISO+U0126 A10:ISO+CILE

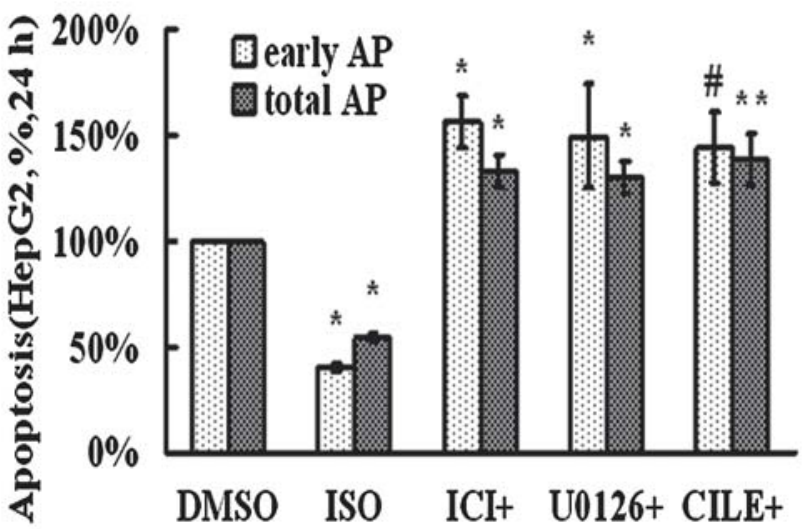

A11: Apoptosis of HepG2

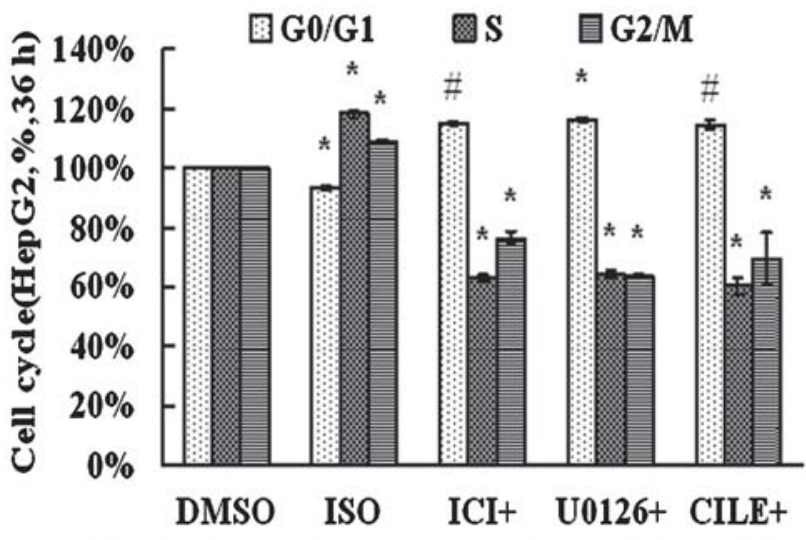

A12: Cell cycle progression of HepG2

Figure 5. Effects of CILE on cell survival and cell cycle progression of HepG2 and MHCC97H cells stimulated by ISO. Cells were serum-starved overnight and incubated with $10 \mu \mathrm{M}$ of ISO for 24 and $36 \mathrm{~h}$ in absence or presence of $5 \mu \mathrm{M}$ of ICI, $10 \mu \mathrm{M}$ of U0126 and $1.2 \mathrm{mg} / \mathrm{ml}$ of CILE. ICI, U0126 and CILE were added $30 \mathrm{~min}$ before ISO. The apoptotic cells and cell cycle progression were evaluated by flow cytometry. (A) A1-A12, effects of CILE on apoptosis and cell cycle progression of HepG2 cells. ${ }^{*} \mathrm{p}<0.05$ versus control $\left(0.1 \%\right.$ DMSO). ${ }^{*} \mathrm{p}<0.05$ versus control and $\mathrm{p}>0.05$ versus U0126. ${ }^{* *} \mathrm{p}<0.05$ versus control and $\mathrm{p}>0.05$ versus ICI. (B) B1-B12, effects of CILE on apoptosis and cell cycle progression of MHCC97H cells. ${ }^{*} \mathrm{p}<0.05$ versus control (0.1\% DMSO). ${ }^{* *} \mathrm{p}<0.05$ versus control and $\mathrm{p}>0.05$ versus ICI. ${ }^{\#} \mathrm{p}<0.05$ versus control and $\mathrm{p}>0.05$ versus U0126.

control, respectively, $\mathrm{p}<0.05)$ were significantly attenuated in presence of ICI, U0126 or CILE (Fig. 4C).

Effect of Chrysanthemum indicum Linné extract on Isoproterenol-induced cell survival and cell cycle progression of HepG2 and MHCC97H cells. The inhibitory effects of CILE on the cell survival and cell cycle progression of HepG2 and MHCC97H cells after ISO stimulation were analyzed by flow cytometry. Serum-starved HepG2 and MHCC97H cells $\left(2 \times 10^{6}\right.$ cells $\left./ \mathrm{ml}\right)$ were incubated $10 \mu \mathrm{M}$ of ISO for 24 and $36 \mathrm{~h}$ in absence or presence of $5 \mu \mathrm{Ms}$ of ICI $118551,10 \mu \mathrm{M}$ of U0126 and $1.2 \mathrm{mg} / \mathrm{ml}$ of CILE. Flow cytometric analysis showed a significant decrease in the percentage of apoptotic cells (HepG2: $54.8 \pm 2 \%$ of control, p <0.05; MHCC97H: $52.37 \pm 8.3 \%$ of control, $\mathrm{p}<0.05$ ) (Fig. $5 \mathrm{~A} 1, \mathrm{~A} 2$, and $\mathrm{A} 11$;
Fig. 5B1, B2 and B11) and a significant increase in the percentage of cells in the $\mathrm{S}$ phase (HepG2: $118.2 \pm 1.2 \%$ of control, $\mathrm{p}<0.05$; MHCC97H: $128.8 \pm 6.6 \%$ of control, $\mathrm{p}<0.05$ ) (Fig. 5A6, A7 and A12; Fig. 5B6, B7 and B12). These effects of ISO were significantly blocked in presence of ICI 118551, CILE and U0126 (Fig. 5A3, A4, A5 and A11; 5B3, B4, B5 and B11; Fig. 5A8, A9, A10, A12; 5B8, B9, B10 and B12). Meanwhile, the percentage of cells in the G0/G1 phase of both HepG2 and MHCC97H was greatly increased in presence of ICI 118551, U0126 and CILE.

\section{Discussion}

Previous studies demonstrated that CILE was cytotoxic to lung, colon, prostate, kidney cancer and melanoma cells (1-6). 
B
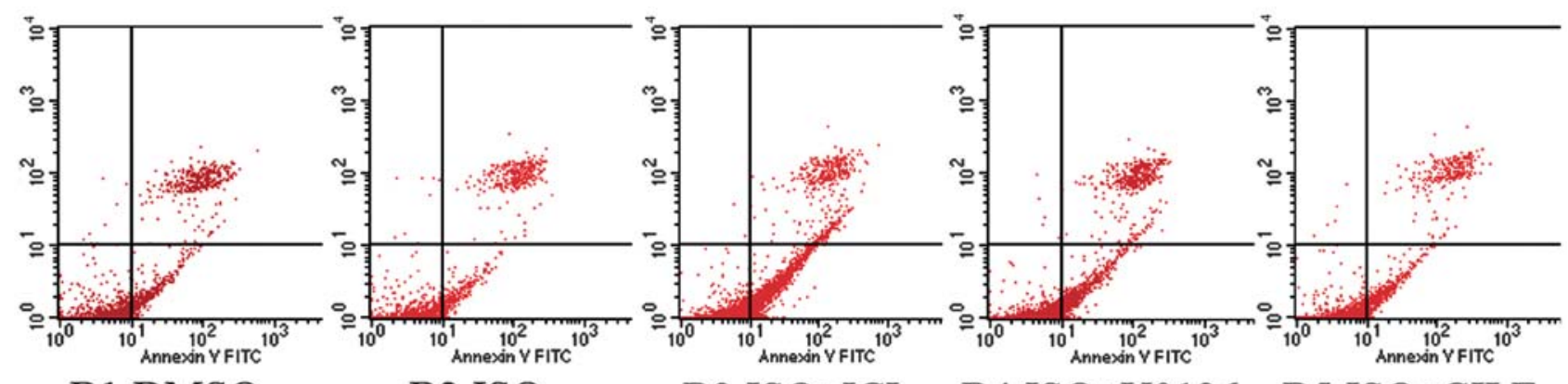

B1:DMSO

B2:ISO

$\mathrm{B} 3: \mathrm{ISO}+\mathrm{ICI}$

B4:ISO+U0126

B5:ISO+CILE

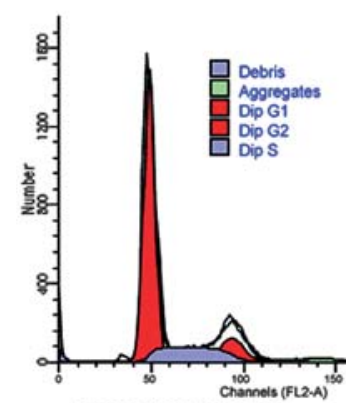

B6:DMSO

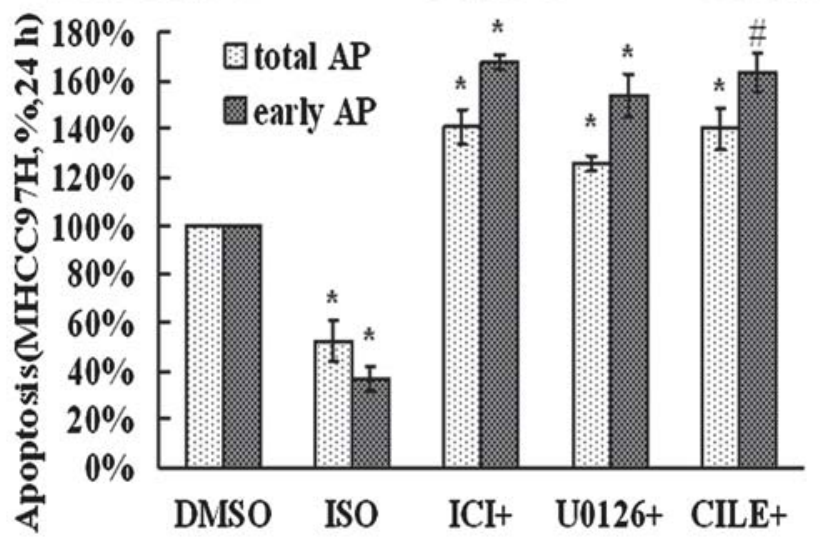

B11: Apoptosis of $\mathrm{MHCC} 97 \mathrm{H}$

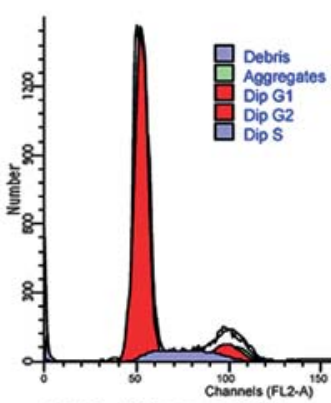

B8:ISO+ICI
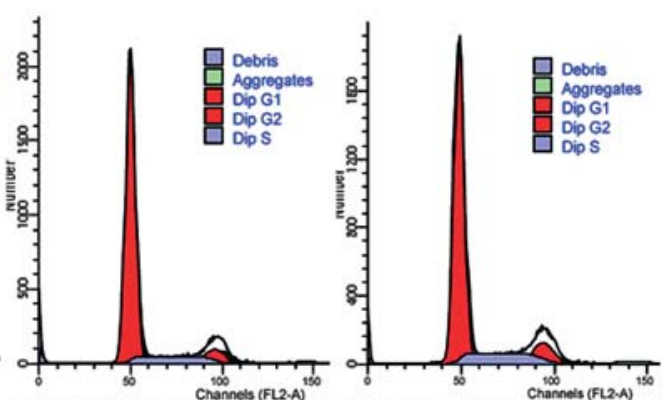

B9:ISO+U0126 B10:ISO+CILE

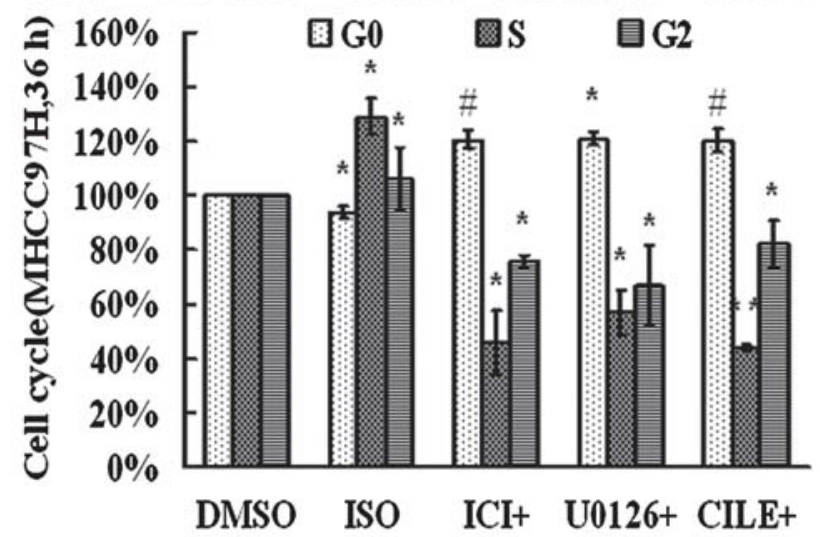

B12: Cell cycle progression

Figure 5. Continued.

The inhibitory activity against cancer cells is suggested to be due to the anti-oxidant, anti-inflammatory, and immunomodulatory functions of CILE. In the present study, we demonstrated that CILE inhibited tumor cell growth by attenuating the mitogenic effect of sympathetic stimulation on human HCC cells.

Firstly, we provided evidence that the specific $B-A R$ agonist isoproterenol (ISO) was a mitogen for human HCC cells and the effect of ISO was efficiently inhibited by CILE. Exposure of HepG2 and MHCC97H cells to ISO resulted in an increased cell proliferation (Fig. 2A and B), enhanced cell survival (Fig. 5A2 and A11; Fig. 5B2 and B11) and accelerated cell cycle progression (Fig. 5A7 and A12; Fig. 5B7 and B12). The increases in growth were proven to be dose-dependent, which was initiated by $100 \mathrm{nM}$ of ISO and peaked by $10000 \mathrm{nM}$ of ISO (Fig. 2A and B). However, the deleterious effect of ISO on the growth of both HepG2 and MHCC97H cells was effectively attenuated by the treatment of CILE (Fig. 2C; Fig. 5A5, A11, A10 and A12; Fig. 5B5, B11, B10 and B12).
Secondly, we provided a primary insight into the possible mechanism that account for the stimulatory effect of ISO and antagonistic effect of CILE on the growth of HepG2 and MHCC97H cells. Clinical studies demonstrated that human HCC exhibited high expression of MAPK/ERK1/2 and the enhanced activity of MAPK/ERK1/2 was associated with rapid tumor progression and poor prognosis $(13,14)$. We focus our study on the stimulatory effect of ISO and the inhibitory effect of CILE on MAPK/ERK1/2 in HepG2 and MHCC97H cells. We found that ISO transiently activated the ERK1/2 in both tumor cell lines (Fig. 3A and B). Moreover, the stimulatory effect of ISO on ERK1/2 was significantly attenuated by the selective B2-AR antagonist ICI 118551, the MEK inhibitor U0126 and CILE (Fig. 3C and D; Fig. 4A and $\mathrm{B})$, resulting in an inhibition of tumor cell growth (Fig. 4C; Fig. 5A3-A5 and A8-A12; Fig. 5B3-B5 and B8-B12). Thus, we demonstrated that CILE was competent in attenuating the stimulatory effect of ISO on ERK1/2 in tumor cells.

In conclusion, our data show that CILE was effective in attenuating the mitogenic effect of ISO on HepG2 and 
MHCC97H cells. The inhibitory effect of CILE was mediated by inhibiting the ISO-induced activation of MAPK/ERK1/2 via $B 2-A R$ in tumor cells. Our findings will be helpful for understanding the anticancer mechanism of CILE.

\section{Acknowledgements}

This work was funded by the 'State Natural Science Funds Committee of China'. We gratefully acknowledge all contributors to 'the Key Laboratory of Environment and Genes Related to Diseases of Ministry of Education of China', especially Professor Chen Huang for valuable scientific discussions. We appreciate the assistance of Rongri Liang for cell culture and we thank Huanchen Sha for FCM analysis.

\section{References}

1. Middleton E Jr, Kandaswami C, and Theoharides TC: The effects of plant flavonoids on mammalian cells: implications for inflammation, heart disease, and cancer. Pharmacology 52: 673-751, 2000

2. Cheng W, Li J, You T, and $\mathrm{Hu} \mathrm{C}$ : Anti-inflammatory and immunomodulatory activities of the extracts from the inflorescence of Chrysanthemum indicum Linné. J Ethnopharmacol 101: 334-337, 2005.

3. Jin S, Zhu P, and Qin X: Effect of wild chrysanthemum injecta on the proliferation of SMMC7721, PC3 and HL60 cells. Pharmacol Clin Chin Mat Med 21: 39-40, 2005.

4. Akihisa T, Tokuda H, Ichiishi E, Mukainaka T, Toriumi M, Ukiya M, Yasukawa K, and Nishino H: Anti-tumor promoting effects of multiflorane-type triterpenoids and cytotoxic activity of karounidiol against human cancer cell lines. Cancer Lett 173 : 9-14, 2001.

5. Yanez J, Vicente V, Alcaraz M, Castillo J, Benavente-Garcia O, Canteras $M$ and Teruel JA: Cytotoxicity and antiproliferative activities of several phenolic compounds against three melanocytes cell lines: relationship between structure and activity. Nutr Cancer 49: 191-199, 2004.

6. Salminen A, Lehtonen M, Suuronen T, Kaarniranta K and Huuskonen J: Terpenoids: natural inhibitors of NF-kappaB signaling with anti-inflammatory and anticancer potential. Cell Mol Life Sci 65: 2979-2999, 2008.

7. Park KH, Yang MS, Park MK, Kim SC, Yang CH, Park SJ and Lee JR: A new cytotoxic guaianolide from Chrysanthemum boreale. Fitoterapia 80: 54-56, 2009.

8. Antoni MH, Lutgendorf SK, Cole SW, Dhabhar FS, Sephton SE, McDonald PG, Stefanek M and Sood A: The influence of bio-behavioural factors on tumour biology: pathways and mechanisms. Nat Rev Cancer 6: 240-248, 2006.
9. Thaker PH, Han LY, Kamat AA, Arevalo JM, Takahashi R, Lu C, Jennings NB, Armaiz-Pena G, Bankson JA, Ravoori M, Merritt WM, Lin YG, Mangala LS, Kim TJ, Coleman RL, Landen CN, Li Y, Felix E, Sanguino AM, Newman RA, Lloyd M, Gershenson DM, Kundra V, Lopez-Berestein G, Lutgendorf SK, Cole SW and Sood AK: Chronic stress promotes tumor growth and angiogenesis in a mouse model of ovarian carcinoma. Nat Med 12: 939-944, 2006.

10. Weddle DL, Tithoff P, Williams $M$ and Schuller HM: BAdrenergic growth regulation of human cancer cell lines derived from pancreatic ductal carcinomas. Carcinogenesis 22: 473-479, 2001

11. Liu X,Wu WK, Yu L, Li ZJ, Sung JY, Zhang ST and Cho CH: Epidermal growth factor-induced esophageal cancer cell proliferation requires transactivation of $\beta$-adrenoceptors. J Pharmacol Exp Ther 326: 69-75, 2008.

12. Pullar CE and Isseroff RR: The $B 2$-adrenergic receptor activates pro-migratory and pro-proliferative pathways in dermal fibroblasts via divergent mechanisms. J Cell Sci 119: 592-602, 2006.

13. Tsuboi Y, Ichida T, Sugitani S, Genda T, Inayoshi J, Takamura M, Matsuda Y, Nomoto M and Aoyagi Y: Overexpression of extracellular signal-regulated protein kinase and its correlation with proliferation in human hepatocellular carcinoma. Liver Int 24: 432-436, 2004.

14. Schmitz KJ, Wohlschlaeger J, Lang H, Sotiropoulos GC Malago M, Steveling K, Reis H, Cicinnati VR, Schmid KW and Baba HA: Activation of the ERK and AKT signalling pathway predicts poor prognosis in hepatocellular carcinoma and ERK activation in cancer tissue is associated with hepatitis $\mathrm{C}$ virus infection. J Hepatol 48: 83-90, 2008.

15. Peng YR, Shi L, Luo YH and Ding YF: Protective effect of total flavones from Chrysanthemum on isoprenaline-induced myocardial ischemia in rats. Lishizhen Med Materia Med Res 7: 1131-1132, 2006.

16. Zhao Q, Matsumoto K, Okada H, Ichiki K and Sakakibara I: Anti-hypertensive and anti-stroke effects of Chrysanthemum extracts in stroke-prone spontaneously hypertensive rats. J Trad Med 25: 143-151, 2008.

17. Lee ER, Kang YJ, Kim JH, Lee HT and Cho SG: Modulation of apoptosis in HaCaT keratinocytes via differential regulation of ERK signaling pathway by flavonoids. J Biol Chem 280: 31498-31507, 2005.

18. Ji Y, Lee HJ, Goodman C, Uskokovic M, Liby K, Sporn M and Nanjoo S: The synthetic triterpenoid CDDO-imidazolide induces monocytic differentiation by activating the Smad and ERK signaling pathways in HL60 leukemia cells. Mol Cancer Ther 5: $1452-1458,2006$ 